\title{
Pendidikan Karakter Melalui Keteladanan Pahlawan Nasional
}

\author{
Yudi Setianto \\ Widyaiswara pada Pusat Pengembangan \& Pemberdayaan Pendidikan dan Tenaga \\ Kependidikan PKn-IPS Malang, Jawa Timur \\ yudiroyan@gmail.com
}

\begin{abstract}
ABSTRAK
Artikel yang berupa gagasan dengan judul "Pendidikan Karakter Melalui Keteladanan Pahlawan Nasional, berawal dari temuan di lapangan, bahwa pembelajaran sejarah bersifat kognitif-oriented , kurang memperhatikan makna didaktis dan afektif. Artikel ini berusaha menemukan solusi agar terjadi perubahan paradigma dalam menyusun dan mengembangkan materi sejarah. Penulisan ini menggunakan pendekatan kualitatif deskriptif-analitik. Pengembangan karakter siswa sebenarnya dapat efektif dengan materi sejarah. Pengintegrasian pendidikan karakter dalam materi sejarah dapat dilakukan melalui keteladanan para Pahlawan Nasional. Para pahlawan tersebut telah teruji integritasnya, sehingga pemerintah memberi penghargaan yang tinggi terkait perjuangan, sikap, pemikiran, dan karakternya. Untuk itu, dalam mengembangkan karakter siswa dapat dilakukan melalui isnpirasi dari pahlawan nasional.
\end{abstract}

Kata Kunci: Materi Sejarah, Pendidikan Karakter, Pahlawan Nasional

\begin{abstract}
An article, which is an idea entitled "Character Education through a National Hero Role Model", begins with a finding in the field, that a History learning tends to be cognitive-oriented as well as inattentive in didactic and affective meanings. This article tries to find out a solution in order that a change of paradigm in compiling and developing a History lesson happens. This process of writing uses qualitative descriptive analytic method. Developing students' character actually can be effective with History lesson. The integration of character education in History lesson can be done by National Heroes role model. Those National Heroes have had proven integrity as a result the government handed award for their struggle, attitude, thoughts and character. For that reason, to develop the students' character can be done through the inspiration from the national hero.
\end{abstract}

Keywords: History Materials, Character Education, National Hero

\begin{abstract}
PENDAHULUAN
Pengajaran sejarah penting dalam pembentukan jiwa patriotisme dan rasa kebangsaan. Suatu pengetahuan sejarah yang ditunjang pengalaman praktis warga negara yang baik di sekolah membantu memperkuat loyalitas dan membantu anak-anak menemukan dirinya dengan latar belakang sejarah luas (Jarolimek, 1971: 221). Rowse (1963: 111) menegaskan bahwa sejarah adalah suatu mata pelajaran yang bernilai pendidikan tinggi. Sementara itu Collingwod (1973: 1520) mengatakan bahwa nilai sejarah adalah mengajarkan kepada kita tentang manusia dan apa yang telah dilakukannya. Dalam konteks pembentukan identitas nasional, pengetahuan
\end{abstract}

sejarah mempunyai fungsi fundamental ( Kartodirdjo, 1993:247). Inti pembelajaran sejarah adalah bagaimana menanamkan nilainilai kepahlawanan, kecintaan terhadap bangsa, jati diri dan budi pekerti kepada anak didik. Buku pelajaran sejarah hendaknya disusun dengan ketentuan-ketentuan ilmiah yang berlandaskan pada tujuan pendidikan nasional ( Hugiono \& Poerwantana, 1987:90). Melalui proses belajar sejarah bukan sematamata menghapal fakta, siswa dapat mengenal kehidupan bangsanya secara lebih baik dan mempersiapkan kehidupan pribadi dan bangsanya yang lebih siap untuk jangka selanjutnya ( Hasan, 1997:141). 
Sementara itu, Krug (1967:22) berpendapat bahwa pengajaran sejarah bangsa merupakan upaya terbaik untuk memperkuat kesatuan nasional dan untuk menanamkan semangat cinta tanah air dan jiwa patriotik. Sedangkan Kartodirdjo (1993:258) menyatakan peranan strategis pengajaran sejarah dalam rangka pembangunan bangsa menuntut suatu penyelenggaran pengajaran sejarah sebagai pemahaman dan penyadaran, sehingga mampu membangkitkan semangat pengabdian yang tinggi, penuh rasa tanggung jawab serta kewajiban. Kepekaannya terhadap sejarah akan melahirkan aspirasi dan inspirasi untuk melaksanakan tugasnya sebagai warga negara. Hugiono \& Poerwantana (1987:88) berpendapat, tujuan mempelajari sejarah tidaklah sama dengan tujuan sejarah, menyangkut persoalan didaktis dan juga filsafat. Tujuan pelajaran sejarah merupakan bagian dari tujuan pendidikan. Sejarah sebagai bahan pelajaran harus disusun searah dengan dasar dan tujuan Pendidikan Nasional. Kartodirdjo (1993:247) berpendapat bahwa pembelajaran sejarah berkedudukan sangat strategis dalam pendidikan nasional sebagai "soko guru" dalam pembangunan bangsa. Pembelajaran sejarah perlu disempurnakan agar dapat berfungsi secara lebih efektif, yaitu penyadaran warga negara dalam melaksanakan tugas kewajibannya dalam rangka pembangunan nasional.

Materi dan mata pelajaran sejarah di Indonesia, selama ini identik dengan materi ataupun mata pelajaran yang membosankan dengan menghapal nama orang atau tokoh, nama tempat, angka tahun, dan sekilas fakta. Pembelajaran sejarah selama ini dikembangkan berdasarkan pemikiran peristiwa penting dalam sejarah, dan bukan berdasarkan peristiwa sejarah apa yang penting bagi siswa. Padahal, materi sejarah sangat efektif dalam pembentukan karakter bangsa. Jika materi sejarah dikaitkan dengan karakter, hal tersebut sangat relevan. Dalam perjalanan setiap bangsa, tokoh-tokoh besarnya sering kali menjadi sumber inspirasi bagi pendidikan karakter dari bangsa tersebut. Dengan demikian, perlu adanya kreativitas dari para pendidik untuk mengembangkan serta menyampaikan materi sejarah dengan memperhatikan keseimbangan antara kognitif dan afektif. Jika nilai afektif dikaitkan dengan kebijakan pemerintah mengenai Penguatan Pendidikan karakter, maka perlu terobosan tersendiri dari para pendidik.
Kajian artikel yang memuat ide , konsep, dan gagasan ini bertujuan untuk merumuskan suatu ide dan konsep alternatif dalam menyampaikan materi sejarah yang berintegrasi dengan penguatan pendidikan karakter. Tujuan mempelajari sejarah di dunia pendidikan khususnya jenjang sekolah dasar sampai sekolah menengah selalu dikaitkan dengan nilai-nilai tertentu seperti pembangunan karakter, semangat nasionalisme, serta nilai-nilai afektif lain yang relevan bagi tujuan pendidikan nasional.

Materi sejarah di perguruan tinggi dengan di sekolah secara esensi tujuannya berbeda. Di perguruan tinggi lebih menekankan pada ilmu murni sejarah yang bersifat bebas nilai. Alasannya, perkembangan pola pikir peserta didik sudah lebih berkembang dan matang. Materi sejarah di sekolah sebagai irisan antara materi ilmu sejarah dan tujuan pendidikan sehingga disebut sebagai pendidikan sejarah atau pembelajaran sejarah. Pembelajaran sejarah menempatkan fakta sejarah yang disaring, demi tujuan pendidikan. Fakta yang disaring dikaitkan dengan tingkat penalaran siswa (Setianto, 2012: 485).

Dari deskripsi di atas, materi sejarah yang diintegrasikan dengan Penguatan Pendidikan Karakter, dapat dirumuskan dalam rumusan masalah sebegai berikut:

1. Bagaimana keterkaitan antara materi pembelajaran sejarah dengan Penguatan Pendidikan Karakter?

2. Bagaimana strategi mengintegrasikan Penguatan Pendidikan Karakter melalui keteladanan para pahlawan nasional?

Artikel jurnal berupa konsep, ide, dan gagasan ini bertujuan untuk: (1) mendeskripsikan keterkaitan antara materi pembelajaran sejarah dengan Penguatan Pendidikan Karakter serta (2) menganalisis strategi dalam mengintegrasikan Penguatan Pendidikan Karakter melalui keteladanan para pahlawan nasional.

Kajian yang mendasari artikel jurnal jenis gagasan, konsep, dan ide ini adalah pendidikan karakter dan pahlawan nasional. Pendidikan karakter akan bersentuhan dengan wilayah filsafat moral atau etika yang bersifat universal, seperti kejujuran. Pendidikan karakter sebagai pendidikan nilai menjadikan "upaya eksplisit mengajarkan nilai-nilai, untuk membantu siswa mengembangkan disposisidisposisi guna bertindak dengan cara-cara yang pasti" (Curriculum Corporation, 2003: 33). Persoalan baik dan buruk, kebajikan- 
kebajikan, dan keutamaan-keutamaan menjadi aspek penting dalam pendidikan karakter semacam ini. Apalagi pembelajaran juga memperhatikan empat pilar pembelajaran sebagaimana telah dideklarasikan oleh Unesco (1988), yaitu: 1) learning to know (pembelajaran untuk tahu), learning to do (pembelajaran untuk berbuat), 3) learning to be (pembelajaran untuk membangun jati diri, dan 4) learning to live together (pembelajaran untuk hidup bersama secara harmonis) (Setiadi dkk, 2007: 2).

Secara istilah di Indonesia, perkataan "pahlawan" berasal dari bahasa Jawa Kuno yang sering ditulis dalam berbagai kitab klasik seperti kitab Ramayana,Bharata Yudda dan Nagarakertagama. Istilah "pahlawan" berasal dari kata "phala" yang mempunyai arti buah atau hasil upah. Dengan demikian, pahlawan dapat diartikan orang yang telah mencapai hasil atau buah dari hasil kerjanya atau usahanya. Pahlawan Nasional dapat diartikan sebagai seseorang yang telah mencapai hasil usahanya atau memetik buahnya dalam usahanya untuk kepentingan nasional atau bangsanya. Dalam hubungan ini, pengertian usaha tidak diartikan sempit melainkan usaha atau perjuangan dalam arti luas untuk kepentingan bangsa ( Tjandrasasmita, 1983: 19). Bersadarkan UU No. 20 Tahun 2009, tentang Gelar, Tanda Jasa, dan Tanda Kehormatan dijelaskan bahwa pahlawan nasional adalah gelar yang diberikan kepada warga negara Indonesia atau seseorang yang berjuang melawan penjajah di wilayah yang sekarang menjadi wilayah NKRI, yang telah gugur atau meninggal dunia demi membela bangsa dan negara, atau yang semasa hidupnya melakukan tindakan kepahlawanan atau menghasilkan prestasi dan karya yang luar biasa bagi pembangunan dan kemajuan bangsa dan negara Republik Indonesia.

\section{METODE PENELITIAN}

Artikel jurnal yang berupa ide, gagasan, dan konsep dengan judul "Pendidikan Karakter Melalui Keteladanan Pahlawan Nasional", berawal dari temuan di lapangan, bahwa pembelajaran sejarah bersifat kognitiforiented, dan belum maksimal pengintegrasian dalam ranah afektif. Artikel jurnal ini berusaha menemukan solusi agar terjadi perubahan paradigma dalam mengembangkan materi sejarah dikaitkan dengan pendidikan karakter. Penulisan ini menggunakan metode kualitatif deskriptif-analitik. Menurut Van Maanen, penelitian kualitatif mengarahkan kegiatannya secara dekat pada masalah kekinian. Kepentingan pokoknya diletakkan pada peristiwa nyata dalam dunia aslinya, bukan sekedar pada laporan yang ada (Van Maanen dalam Sutopo, 2006:36).

\section{HASIL \& PEMBAHASAN}

\section{Hakekat Pembelajaran Sejarah}

Hamid Hasan berpendapat, terdapat beberapa pemaknaan terhadap pendidikan sejarah. Pertama, secara tradisional pendidikan sejarah dimaknai sebagai upaya untuk mentransfer kemegahan bangsa di masa lampau kepada generasi muda. Dengan posisi yang demikian maka pendidikan sejarah adalah wahana bagi pewarisan nilai-nilai keunggulan bangsa. Melalui posisi ini pendidikan sejarah ditujukan untuk membangun kebanggaan bangsa dan pelestarian keunggulan tersebut. Kedua, pendidikan sejarah berkenaan dengan upaya memperkenalkan peserta didik terhadap disiplin ilmu sejarah. Oleh karena itu kualitas seperti berpikir kronologis, pemahaman sejarah, kemampuan analisis dan penafsiran sejarah, kemampuan penelitian sejarah, kemampuan analisis isu dan pengambilan keputusan (historical issues-analysis and decision making) menjadi tujuan penting dalam pendidikan sejarah ( Hamid, 2007: 7).

Widja (1989: 23) menyatakan bahwa pembelajaran sejarah adalah perpaduan antara aktivitas belajar dan mengajar yang di dalamnya mempelajari tentang peristiwa masa lampau yang erat kaitannya dengan masa kini. Pendapat I Gde Widya tersebut dapat disimpulkan jika mata pelajaran sejarah merupakan bidang studi yang terkait dengan fakta-fakta dalam ilmu sejarah namun tetap memperhatikan tujuan pendidikan pada umumnya. Dalam Seminar Sejarah Nasional di Yogyakarta tahun 1957, Padmopuspito berpendapat bahwa pertama, penyusunan pelajaran sejarah harus bersifat ilmiah. Kedua, siswa perlu bimbangan dalam berfikir tetapi tafsiran dan penilaian tidak boleh dipaksakan, karena dapat mematikan daya pikir siswa (Gasalba, 1966:169).

Atas dasar hal tersebut, maka materi sejarah diberikan kepada seluruh siswa jenjang sekolah. Kedudukannya yang penting dan strategis dalam pembangunan watak bangsa merupakan fungsi yang tidak bisa digantikan oleh mata pelajaran lainnya. Meskipun demikian, terkait dengan materi sejarah dari jenjang tingkat dasar sampai menengah, Taufik Abdullah berpendapat agar siswa tidak bosan menerima materi sejarah, maka jika secara 
faktual yang disampaikan sama namun dalam setiap jenjang pendidikan, peristiwa tersebut akan tampil pada tingkat pengetahuan, pemahaman, serta pemberian keterangan sejarah yang semakin tinggi dan kompleks. Dengan demikian, setiap tingkatan atau tahap diharapkan bisa memberikan kesegaran dan kematangan intelektual (Abdullah, 1996: 10).

Dalam masa pembangunan bangsa, salah satu fungsi utama pendidikan adalah pengembangan kesadaran nasional sebagai sumber daya mental dalam proses pembangunan kepribadian nasional beserta identitasnya (Kartodirdjo, 1993:247). Tujuan pendidikan tidak hanya membentuk kemampuan intelektual semata, tetapi juga sikap dan berbagai ketrampilan. Jika pendidikan hanya memberikan kemampuan intelektual tanpa didasari nilai-nilai dan moralitas dalam diri siswa, maka intelektualitas dapat menjadi salah arah. Menurut Kohlberg (1995:63), pendidikan moral lebih merupakan perangsang bagi perkembangan moral daripada ajaran langsung tentang aturan-aturan moral yang pasti dan baku.

Menurut Nugroh Notosusanto, secara umum, fungsi sejarah terdiri empat macam meliputi:

(1) Fungsi Edukatif, sejarah memberikan kearifan dan kebijakan bagi yang mempelajari

(2) Fungsi Inspiratif, dari sejarah dapat diambil ide-ide dan konsep yang langsung berguna bagi pemecahan masalah masa kini dan untuk mendapatkan inspirasi dan semangat bagi mewujudkan identitas sebagai suatu bangsa.

(3) Fungsi Rekreatif, yaitu nilai estetis dari sejarah, terutama berupa cerita yang indah tentang tokoh ataupun peristiwa.

(4) Fungsi Instruktif, untuk menunjang bidang studi kejuruan/ketrampilan seperti jurnalistik,tehnologi senjata, navigasi dan lain-lain (Notosusanto, 1971: 7-12).

Tampaknya, cari berbagai hal tentang pembelajaran sejarah serta hakekat dari keempat fungsi sejarah di atas, pelaksanaan pembelajaran di Indonesia hanya terpaku pada fungsi rekreatif berupa cerita sebuah peristiwa beserta tokohnya yang dikemas secara kronologis-diakronis. Jika ini dilakukan maka menjadi pembenar sebagian pendapat bahwa pembelajaran sejarah bersifat monoton dan membosankan bagi siswa. Hal ini sesuai pendapat Magdalia Afian bahwa strategi pedagogis sejarah Indonesia sangat lemah.
Pendidikan sejarah di sekolah masih berkutat pada pendekatan chronicle dan cenderung menuntut anak agar menghafal suatu peristiwa. Pengaruh pembelajaran sejarah nasional masih terus dipertanyakan keberhasilannya, mengingat fenomena kehidupan berbangsa dan bernegara Indonesia khususnya generasi muda makin hari makin diragukan eksistensinya. Dengan kenyataan tersebut artinya ada sesuatu yang harus dibenahi dalam pelaksanaan pendidikan sejarah ( Alfian, 2007).

Jika materi pembelajaran sejarah, khususnya membahas para pahlawan bangsa di Indonesia diajarkan secara berulang-ulang dari tingkat SD sampai SMA, maka muncul kejenuhan pada diri siswa. Pelajaran sejarah menjadi kurang memberi kesempatan kepada anak didik untuk belajar menggali peristiwa atau tokoh lain dalam sejarah serta mengali lebih dalam tentang perilaku, sikap, perjuangan dan pemikiran dari para pahlawan. Selama ini, dalam buku-buku teks pelajaran sejarah hanya terdapat beberapa peristiwa dan pahlawan atau tokoh ketika membahas materi perlawanan atau perjuangan bangsa melawan kolonialisme dan imperialisme. Tokoh-tokoh pahlawan tersebut adalah Pangeran Diponegoro, Imam Bonjol, Sultan Agung, Pattimura, R.A Kartini serta tokoh pahlawan lain yang sudah dihapal oleh para siswa. Hapalan materi pada umumnya tentang siapa, kapan, dimana, dan apa dari tokoh tersebut.

Padahal sejarah Indonesia yang panjang mengandung berbagai nilai edukatif sehingga memberikan pelajaran yang penting bagi kehidupan generasi penerus bangsa. Untuk terus menghidupkan penghargaan terhadap sejarah bangsa, materi pembelajaran sejarah harus bisa diterapkan dengan inovasi materi yang menarik minat siswa. Menarik di sini tetap berdasar ciri khas materi sejarah namun dikaitkan dengan hal yang bersifat kontekstual

Selama ini fungsi sejarah terkait dengan pengembangan karakter bangsa yakni fungsi edukatif belum diimplementasikan. Padahal jika materi sejarah dikaitkan dengan sejarah dalam koridor pendidikan di sekolah maka dengan sendirinya fungsi edukatif lebih ditonjolkan, termasuk materi sejarah di Sekolah Dasar. Namun model dan teknik pembelajaran masih perlu membutuhkan inovasi-kreasi dalam pelaksanaannya di kelas agar mindset tentang materi sejarah bersifat hapalan dan akhirnya terlupakan dapat diubah.

Menurut Sartono Kartodirjo, dua fungsi sejarah yaitu fungsi genetis dan 
didaktis. Pada hakekatnya pengetahuan sejarah adalah pengungkapan tentang "bagaimana" terjadinya peristiwa itu. Sudah barang tentu penjelasan tentang "bagaimana" juga mencakup "apa", "siapa", "di mana", dan "kapan". Esensi dari setiap pengetahuan sejarah sebenarnya hendak menerangkan bagaimana sesuatu terjadi dan dengan demikian, dianggap telah "diterangkan" atau "dijelaskan" peristiwa itu. Ini berarti bahwa sejarah pada hakekatnya wajib melacak perkembangan kejadian, jadi genetikanya. Adapun fungsi didaktis pengetahuan sejarah ialah agar generasi yang berikut dapat mengambil hikmah dan pelajaran dari pengalaman nenek moyangnya. Lagi pula, agar suri tauladan mereka dapat menjadi model bagi keturunannya. Sejarah dianggap sebagai perbendaharaan kebijaksanaan nenek moyang, termasuk nilai-nilainya (Kartodirdjo, 1993:251-252).

Fungsi sejarah menurut Sartono Kartodirdjo di atas, dalam praktek pembelajarannya juga hanya terpaku pada fungsi genetis yang mencakup pengungkapan fakta sejarah yang berhubungan dengan : bagaimana, apa, siapa, di mana. Namun fungsi didaktis agar generasi berikutnya dapat mengambil keteladanan dari fakta sejarah masa lalu, kurang ditekankan. Jika demikian maka slogan kebanggaan sejarah yakni histories make man wise tidak dapat berfungsi secara maksimal. Slogan tersebut dapat diterapkan jika pembelajaran materi sejarah juga dapat berkontribusi dalam hal pembentukan karakter generasi bangsanya.

Pendidikan di Indonesia selama ini dianggap oleh sebagian kalangan mengalami krisis dalam pembentukan karakter . Hal ini disebabkan kurikulum difokuskan pada materi kognitif semata, tanpa memperhatikan secara serius hal-hal afektif atau perilaku. Mata pelajaran dan materi yang relevan dan efektif dalam membangun karakter bangsa, menumbuhkan nasionalisme, dan mempertahankan kearifan lokal adalah mata pelajaran atau materi sejarah. Namun selama mata pelajaran tersebut bersifat mati suri jika dikaitkan pembelajaran sikap. Hal ini disebabkan masih terbatasnya pengintegrasiannya dalam ranah afektif. Kurikulum pembelajaran sejarah dirancang pada domain kognitif semata meski kurikulum mengalami dinamika sesuai perkembangan.

Nilai-nilai karakter dalam pendidikan sejarah memang perlu dilakukan dan diterapkan dalam kurikulum yang ada di sekolah. Hal ini bertujuan untuk membentuk kepribadian siswa yang cinta terhadap tanah airnya sendiri serta tahu bagaimana sejarah negaranya sendiri.Tantangan pendidikan karakter dalam mata pelajaran atau materi sejarah di sekolahsekolah itu sendiri adalah bagaimana mengelola semua komponen-komponen yang ada, seperti isi kurikulum itu sendiri harus lebih mengarahkan pada pembentukan karakter siswa, pemberdayaan sarana dan prasarana, dan etos kerja seluruh warga dan lingkungan sekolah. Apalagi pemerintah sudah memberikan aturan tentang penguatan pendidikan karakter. Dengan demikian, kurikulum sekolah perlu adanya pengintegrasian pendidikan karakter dalam setiap mata pelajaran dari semua jenjang pendidikan.

Karakter merupakan perpaduan antara moral, etika, dan akhlak. Moral lebih menitikberatkan pada kualitas perbuatan, tindakan atau perilaku manusia atau apakah perbuatan itu bisa dikatakan baik atau buruk, atau benar atau salah. Sebaliknya, etika memberikan penilaian tentang baik dan buruk, berdasarkan norma-norma yang berlaku dalam masyarakat tertentu, sedangkan akhlak tatanannya lebih menekankan bahwa pada hakikatnya dalam diri manusia itu telah tertanam keyakinan di mana ke duanya (baik dan buruk) itu ada. Karenanya, pendidikan karakter dimaknai sebagai pendidikan nilai, pendidikan budi pekerti, pendidikan moral, pendidikan watak, yang tujuannya mengembangkan kemampuan peserta didik untuk memberikan keputusan baik-buruk, memelihara apa yang baik itu, dan mewujudkan kebaikan itu dalam kehidupan sehari-hari dengan sepenuh hati.

Nilai merupakan suatu yang luhur, yang baik dan senantiasa dikejar dan ingin dicapai oleh setiap manusia. Nilai bersifat abstrak atau metafisis, hanya menjadi tampak atau nyata dalam perilaku orang-orang yang menghayatinya. Nilai mengatasi fisik dan kesadaran manusia, namun senantiasa menjadi sesuatu segi yang mendorong berperilaku tertentu. Pemahaman suatu nilai bukanlah suatu kognitif verbal, melainkan yang efektif afektual dengan menghayati nilai itu sendiri (Driyarkara, 1980: 20).

Mengutip pendapat Scheler, Drijarkara menyatakan bahwa unsur pertama dalam kehidupan manusia yang utama adalah nilainilai (wert). Baginya nilai bukanlah sesuatu yang hanya ada dalam pikiran. Nilai bukan ide 
atau cita-cita. Nilai dialami dengan penuh getaran jiwa, perjuangan antara manusia dan nilai rasa (fuhlen) karena ada tiga macam, maka nilai pun ada tiga, yaitu nilai keindahan atau kenikmatan, nilai kebaikan dan nilai rokhani (Driyarkara, 1980: 149-150). Pernyataan Scheler sesuai dengan pendapat Kattsoff ( 1992:345) yang menyatakan bahwa nilai tidak bereaksi namun mempunyai essensiessensi yang terkandung di dalam sesuatu atau perbuatan dan ada di dalam kenyataan. Nilai mendasari barang sesuatu yang "bernilai" maka ia memahami bahwa di dalam hakikat sesuatu terdapat nilai yang mendasari.

Nilai-nilai itu merupakan sesuatu yang nyata, tetapi melekat pada sesuatu. Di dalam nilai terkandung cita-cita, harapan, dambaan, dan keharusan, tetapi bukan merupakan tujuan konkret. Nilai mendorong manusia yang menghayatinya untuk memilih mana yang penting dan tidak penting, benar dan tidak benar, baik dan tidak baik. Dengan demikian, nilai memberi arah untuk bersikap dan bertingkah laku. Setiap bangsa di dunia mempunyai dasar atau landasan, kekuatan dan daya dorong bagi perjuangannya yang berupa nilai-nilai kejuangannya dalam mewujudkan cita-citanya.

Sementara itu, terminologi "karakter" itu memuat dua hal: values (nilai-nilai) dan kepribadian. Suatu karakter merupakan cerminan dari nilai apa yang melekat dalam sebuah entitas. "Karakter yang baik" pada gilirannya adalah suatu penampakan dari nilai yang baik pula yang dimiliki oleh orang atau sesuatu, di luar persoalan apakah "baik" sebagai sesuatu yang "asli" ataukah sekadar kamuflase. Karakter adalah watak, tabiat, akhlak, atau kepribadian seseorang yang terbentuk dari hasil internalisasi berbagai kebajikan (virtues) yang diyakini dan digunakan sebagai landasan untuk cara pandang, berpikir, bersikap, dan bertindak. Kebajikan terdiri atas sejumlah nilai, moral, dan norma, seperti jujur, berani bertindak, dapat dipercaya, dan hormat kepada orang lain. Interaksi seseorang dengan orang lain menumbuhkan karakter masyarakat dan karakter bangsa. Oleh karena itu, pengembangan karakter bangsa hanya dapat dilakukan melalui pengembangan karakter individu seseorang.

\section{Pendidikan Karakter dan Keteladanan Pahlawan Nasional}

Melalui pendidikan sejarah yakni dalam bentuk kegiatan belajar mengajar, proses sosialisasi sikap nasionalisme dapat dilaksanakan secara lebih sistematik dan terencana, yaitu melalui proses internalisasi. Proses internalisasi merupakan proses untuk menjadikan suatu sikap sebagai bagian dari kepribadian seserorang. Dalam upaya mensosialisasikan sikap nasionalisme, strategi belajar mengajar pendidikan sejarah dilakukan melalui tahap pengenalan dan pemahaman, tahap penerimaan, dan tahap pengintegrasian (Hizam: 2007:289).

Sejarah dapat dimaknakan sebagai rekaman kritis tentang peristiwa, pengalaman serta kejadian penting yang dilakukan umat manusia pada masa lalu. Dalam peristiwa sejarah tersebut, akan terlihat nilai-nilai sejarah, sehingga dapat digunakan sebagai referensi dari tindakan dan pola pikir generasi berikutnya dalam suatu bangsa. Mempelajari sejarah bukan sekedar hapalan atau hanya sekedar cerita tentang suatu peristiwa besar yang kemudian kita lupakan dan tanpa memperoleh pemahaman sedikitpun. Peristiwa sejarah mengandung nilai karakter pendidikan sejarah. Selanjutnya, perlu digambarkan implementasi nilai karakter pendidikan sejarah.

Pembelajaran harus memiliki muatan konsep kurikulum tersembunyi (hidden curriculum), yang meliputi nilai-nilai yang dipromosikan oleh sekolah, penekanan yang diberikan oleh guru, derajat antusiasme guru, iklim fisik dan sosial sekolah (Oliva, 1982:7). Istilah hidden curriculum atau kurikulum tersamar menunjuk pada kenyataan bahwa para guru dan sekolah terlibat dalam pendidikan moral, tanpa secara eksplisit dan filosofis membahas atau merumuskan tujuan dan metodenya (Kohlberg, 1995:124). Pendidikan karakter akhir-akhir ini menjadi pembicaraan utama pendidikan, selain menjadi bagian dari proses pembentukan akhlak anak bangsa. Pendidikan karakter diharapkan mampu menjadi pondasi utama dalam mensukseskan bangsa ini sejajar dengan bangsa-bangsa maju lainnya. Dalam UU No 20 Tahun 2003 Tentang Sistem Pendidikan Nasional pada Pasal 3, menyebutkan bahwa pendidikan nasional berfungsi mengembangkan kemampuan dan membentuk karakter serta peradaban bangsa yang bermartabat dalam rangka mencerdaskan kehidupan bangsa. Pendidikan nasional bertujuan untuk berkembangnya potensi peserta didik agar menjadi manusia yang beriman dan bertakwa kepada Tuhan Yang Maha Esa, berakhlak mulia, sehat, berilmu, cakap, kreatif, mandiri, 
dan menjadi warga negara yang demokratis serta bertanggung jawab.

Pendidikan karakter memiliki esensi dan makna yang sama dengan pendidikan moral dan pendidikan akhlak. Tujuannya adalah membentuk pribadi anak, supaya menjadi manusia yang baik, warga masyarakat, dan warga negara yang baik. Adapun kriteria manusia yang baik, warga masyarakat yang baik, dan warga negara yang baik bagi suatu masyarakat atau bangsa, secara umum adalah nilai-nilai sosial tertentu, yang banyak dipengaruhi oleh budaya masyarakat dan bangsanya. Oleh karena itu, hakikat dari pendidikan karakter dalam konteks pendidikan di Indonesia adalah pendidikan nilai, yakni pendidikan nilai-nilai luhur yang bersumber dari budaya bangsa Indonesia sendiri, dalam rangka membina kepribadian generasi muda.

Dalam ranah praktis dalam pendidikan, pendidikan karakter adalah segala sesuatu yang dilakukan guru, yang mampu mempengaruhi karakter peserta didik. Guru membantu membentuk watak peserta didik. Hal ini mencakup keteladanan bagaimana perilaku guru, cara guru berbicara atau menyampaikan materi, bagaimana guru bertoleransi, dan berbagai hal terkait lainnya. Jika dikaitkan dengan nilai karakter pendidikan sejarah, maka hal ini merupakan persitiwa dan tokoh sejarah, yang mampu memberi insipiarsi, keteladadan, dan kepeloporan dari ranah sejarah bangsa Indonesia.

Pendidikan sejarah memiliki peran penting dalam pembinaan generasi muda, karena pendidikan sejarah sebagai saran efektif dalam menanamkan sikap kesetiaan dan tanggung jawab warga negara terhadap bangsa dan negaranya, serta membentuk kepribadian bangsa (Soedjatmoko, 1990: 112). Implementasi nilai karakter dalam pendidikan sejarah dapat dieksplorasi melalui keteladaan para tokoh-tokoh sejarah bangsa yang telah mengabdi dan berjasa bagi bangsa dan negara. Keteladan para tokoh akan memberi keteladanan yang bersifat tekstual dan kontekstual terhadap para siswa.

Keteladanan berasal dari kata teladan yaitu hal - hal yang dapat ditiru atau dicontoh. Keteladanan mempunyai pengaruh besar dalam pembentukan pribadi seseorang. Secara sederhana keteladanan memerlukan penilaian bahwa perilaku tersebut baik sebelum memutuskan untuk melakukan hal yang sama. Keteladanan dapat diartikan wujud dari usaha yang dilakukan seseorang dengan sadar tercermin pada sikap perilaku untuk mencapai tujuan tertentu. Keberhasilannya dapat diukur dengan indikator perubahan perilaku orang yang menjadikannya figur panutan menjadi selaras seimbang sesuai dengan tujuan tertentu yang dikehendaki.

Sebuah proses meniru dan mengikuti selalu terjadi pada diri manusia. Binatang pun belajar dari induk mereka dengan cara melihat, lantas menirukan. Seluruh makhluk hidup di dunia selalu belajar dengan cara meniru, kenyataan - kenyataan di atas, menjelaskan dengan sangat tegas akan pentingnya keteladanan dalam hidup. Karena setiap orang punya tabiat meniru, maka pihak - pihak yang dimungkinkan akan ditiru semestinya selalu tampil sebagai teladan yang baik. Agar, mereka yang meniru mendapatkan contoh yang baik untuk ditiru. Tabiat meniru ini, bahkan akan memberi kontribusi yang besar bagi hampir seluruh kepribadian seseorang.

Banyak pihak yang semestinya memberikan figur teladan yang baik, seperti contoh seorang kepala keluarga menjadi figur teladan bagi anak dan isterinya. Semua pemikiran, ucapan dan tindakan yang dilakukan akan menjadi fokus perhatian anggota keluarganya. Keselarasan dan keseimbangan ketiga hal tersebut mampu berdampak positif bagi pencapaian tujuan dalam kepemimpinan sebuah rumah tangga. Bisa dibayangkan betapa hebatnya akibat yang ditimbulkan bila hal tersebut diterapkan pada lingkungan yang lebih luas, mungkin sebuah negara yaitu keteladanan seorang pemimpin negara. Keteladanan mampu mempengaruhi orang lain yang berbeda latar belakang, budaya, karakter, watak, lingkungan dan pengetahuan.

Strategi keteladanan ini dapat dibedakan menjadi keteladanan internal (internal modelling) dan keteladanan eksternal (external modelling). Keteladanan internal dapat dilakukan melalui pemberian contoh yang dilakukan oleh orang tua terhadap anaknya, atau keteladanan seorang guru terhadap siswanya sendiri dalam proses pembelajaran. Sementara keteladanan eksternal dilakukan dengan pemberian contohcontoh yang baik dari para tokoh yang dapat diteladani, tokoh-tokoh yang ada dalam sejarah bangsa. Pendekatan ini digunakan melalui penerapan strategi keteladanan (modeling) melalui pendidikan sejarah akan efektif.Keteladanan para pahlawan bangsa sebagai sarana efektif dalam rangka 
menumbuhkan kesadaran bermasyarakat, berbangsa dan bernegara.

Nama-nama para pahlawan nasional sebagai model kongkrit dalam pendidikan karakter. Mereka telah teruji integritas dan keteladananya sehingga negara memberi penghargaan melalui gelar pahlawan nasional. Tindakan, kisah, latar belakang, perjuangan dan pemikirannya yang "bernilai" dapat menjadi referensi dan inspirasi dalam kegiatan pembelajaran sejarah. Nilai-nilai karakter, perilaku, pemikiran, dan perjuangannya dapat digali dan dikembangkan melalui pembelajaran sejarah yang bermakna. Dengan demikian para siswa dapat menerima keteladan kongkrit. Untuk itu dituntut adanya kreativitas dari para guru yang menyajikan materi sejarah. Para guru dapat menggali dan mampu mentransformasikan nilai-nilai tertentu kepada peserta didik. Pahlawan tidak selalu identik dengan masalah perang dan perjuangan fisik. Hal ini disebabkan mereka berjuang dari berbagai dimensi. Integritas para pahlawan tersebut dianggap punyai nilai lebih. Dengan demikian, para siswa tidak akan mengalami krisis keteladanan dari tokoh bangsanya sendiri. Jika siswa Sekolah Dasar mengalami krisis keteladanan, maka figur-figur dari tokoh bangsa lain bahkan figur imajinatif fiktif dari media massa malah menjadi tumpuan keteladanan para generasi bangsa. Figur tokoh bangsa lain dan juga figur imajinatif belum tentu sesuai dengan karakter bangsa.

Harus diakui, keteladanan tokoh dan pahlawan bangsa selama ini kurang digali disebabkan metode pembelajaran sejarah masih mengacu pada model konvensional. Pembelajaran sejarah konvensianal hanya terpaku pada peristiwa, nama tokoh, tempat, tahun, dan sepenggal kisah dari tokoh tersebut. Dengan bahasa lain, materi sejarah bertumpu pada penguasaan materi kognitif. Meski kurikulum sejarah dan materi sejarah selalu mengalami perubahan namun hanya berubah di permukaan, secara esensi tetap sama yakni kognitif-oriented (Setianto, 2018: 133). Jika kurikulum demikian, maka siswa tidak pernah merasa adanya hal yang afektif termasuk keteladanan dari sikap, tindakan dan pemikiran para pahlawan dan tokoh bangsa.

Melihat fenomena di atas, para guru yang menyampaikan materi sejarah, perlu melakukan kreasi dan inovasi materi pembelajaran dengan mengintegrasikan keteladan para tokoh sejarah untuk memperkuat pendidikan karakter. Dengan demikian, para guru perlu melakukan terobosan akademik dengan mencari sumbersumber bacaan yang dapat dipertanggungjawabkan secara ilmiah tentang ketokohan para pahlawan nasional jika dikaitkan dengan karakter bangsa.

Dengan demikian program Penguatan Pendidikan Karakter yang telah dicanangkan oleh pemerintah melalui Peraturan Presiden Republik Indonesia Nomor 87 tahun 2017, dapat dilaksanakan oleh berbagai segi dan elemen pendidikan, termasuk melalui materi sejarah di sekolah. Indonesia sebagai bangsa yang berbudaya merupakan negara yang menjunjung tinggi akhlak mulia, nilai-nilai luhur, kearifan, dan budi pekerti. Dalam rangka mewujudkan bangsa yang berbudaya melalui penguatan nilai-nilai religius, jujur, toleran, disiplin, bekerja keras, kreatif, mandiri, demokratis, rasa ingin tahu, semangat kebangsaan, cinta tanah air, menghargai prestasi, komunikatif, cinta damai, gemar membaca, peduli lingkungan, peduli sosial, dan bertanggung jawab, perlu penguatan pendidikan karakter.

Nilai-nilai penguatan karakter dalam

Peraturan Presiden tersebut oleh Kementerian Pendidikan Dan Kebudayaan diimplementasikan melaluiPeraturan Menteri Pendidikan dan Kebudayaan tentang Penguatan Pendidikan Karakter pada Satuan Pendidikan Formal. Nilai-nilai penguatan karakter dilaksanakan dengan menerapkan nilai-nilai Pancasila tersebut dirangkum menjadi lima nilai utama karakter yang saling berkaitan yaitu religiusitas, nasionalisme, kemandirian, gotong royong, dan integritas yang terintegrasi dalam kurikulum.

Lima utama nilai karakter serta subnilai dari karakter dalam pembelajaran tentang materi sejarah, relevan, sesuai dan kontekstual jika materi keteladanan pahlawan nasional menjadi sumber belajar, inspirasi, acuan dan keteladanan jika dihubungkan dengan Penguatan Pendidikan Karakter. Masing-masing tokoh ataupun para pahlawan nasional dapat diidentifikasikan peran, perjuangan, dan pemikirannya dari masingmasing nilai karakter tersebut. Dengan demikian, Penguatan Pendidikan Karakter melalui materi sejarah diharapkan akan lebih efektif dan kontekstual, ditengah-tengah permasalahan bangsa yang mengalami krisis keteladan ini. 


\section{KESIMPULAN \& SARAN}

Selama ini slogan kebanggaan mempelajari sejarah yakni "sejarah membuat bijaksana" seringkali menjadi tanda tanya besar, ketika materi sejarah di sekolah kurang menimbulkan dampak bagi peserta didik. Dampak yang dimaksud di sini bukan sematamata dari aspek kognitif, namun lebih pada aspek afektif. Hal ini disebabkan selama ini, materi sejarah di sekolah memang lebih banyak diajarkan dari sudut kognitif. Materi sejarah pada umumnya bersifat kronologis yang padat dengan materi hapalan berupa "kapan", "siapa", "dimana" tentang suatu fakta sejarah. Akibatnya, materi kognitif yang terlalu padat kurang memberi kesempatan kepada para guru untuk mengajarkan aspek afektifnya.

Aspek afektif dalam pembelajaran sejarah dapat diintegrasikan jika materi sejarah dikaitkan dengan keteladan para tokoh pahlawan. Keteladanan tokoh pahlawan sinergis dengan pendidikan karakter. Keteladan para pahlawan dapat diidentifikasikan dengan nilai-nilai karakter dan subnilai karakter. Dengan demikian, ketika para pahlawan menjadi inspirasi dalam pendidikan penguatan karakter maka materi yang disajikan pada siswa sudah bukan dalam ranah abstrak namun menjadi lebih konkrit , kontekstual dan keindonesiaan.

Dengan demikian, para pendidik yang mengajarkan materi sejarah perlu melakukan inovasi dan kreasi dalam mengembangkan materi pembelajaran sejarah, yang dikaitkan dengan pendidikan karakter melalui isnpirasi para pahlawan nasional. Para Pahlawan Nasional yang ditetapkan oleh pemerintah telah dianggap mempunyai jiwa, tindakan, pemikiran dan perjuangan bagi masyarakat, bangsa dan negara dimana di dalam diri para pahlawan tersebut terdapat nilai-nilai tertentu yang dapat menjadi referensi bagi pengembangan karakter para peserta didik.

\section{DAFTAR PUSTAKA}

Abdullah, Taufik . (1996). " Di Sekitar Pengajaran Sejarah yang Refkletif dan Inspiratif". Dalam Jurnal Sejarah Pemikiran, Rekonstruksi, Persepsi 6 oleh Masyarakat Sejarawan Indonesia. Jakarta: PT Gramedia Pustaka Utama
Alfian, Magdalia. (2007). "Pendidikan Sejarah dan Permasalahan yang Dihadapi". Makalah disampaikan dalam Seminar Nasional Ikatan Himpunan Mahasiswa Sejarah Se-Indonesia (IKAHIMSI). Universitas Negeri Semarang, Semarang, 16 April 2007

Curriculum Corporation. (2003). The Values Education Study: Final Report. Victoria: Australian Government Dept. of Education, Science and Training

Collingwod,R.G. (1973). The Idea of History. London: Oxford University Press

Driyarkara, (1980). Driyarkara Tentang Pendidikan. Yogyakarta: Yayasan Kanisius.

Gazalba, Sidi . (1966). Pengantar Sejarah Sebagai Ilmu. Jakarta: Bhatara Karya Aksara.

Hugiono \& Poerwantana,P.K. (1987). Pengantar Ilmu Sejarah. Jakarta : PT Bina Aksara

Hasan, Hamid S. (1997). "Kurikulum dan Buku Teks Sejarah" dalam Kongres Nasional Sejarah 1996 Jakarta Sub Tema Perkembangan Teori dan Metodologi dan Orientasi Pendidikan Sejarah. Jakarta : Proyek Inventarisasi dan Dokumentasi Sejarah Nasional Direktorat Jenderal Kebudayaan Departemen Pendidikan dan Kebudayaan

Hasan, Hamid S. (2007). 'Kurikulum Pendidikan Sejarah Berbasis Kompetensi'. Makalah pada Seminar Nasional Ikatan Himpunan Mahasiswa Sejarah Se-Indonesia (Ikahimsi) XII. Semarang, 16 April 2007.

Hizam, Ibnu. (2007). "Kontribusi Minat Belajar dan Kemampuan Klarifikasi Nilai Sejarah dalam Pembentukan Sikap Nasionalisme" dalam Jurnal Penelitian Keislaman, Vol. 3, No. 2, Juni 2007.

Jarolimek, John. (1971). Social Studies in Elementary Education.Ney York: Macmillan Co.

Kartodirdjo, Sartono.(1993).Pendekatan Ilmu Sosial dalam Metodologi Sejarah. Jakarta: PT Gramedia Pustaka Utama

Krug, Mark. M. (1967). History and the Social Sciences. Walthan Mass: Braisdell 
Kohlberg, Lawrence. (1995). Tahap-tahap Perkembangan Moral. (Edisi terjemahan oleh John de Santos dan Agus Cremers SUD. Yogyakarta: Kanisius

Kattsoff, Louis. (1992). Pengantar Filsafat. Yogyakarta: Tiara Wacana.

Notosusanto, Nugroho. (1971). Norma-norma Dasar Penelitian dan Penulisan Sejarah. Jakarta: Pusat Sejarah ABRI, Departemen Hankam.

Oliva, Peter F. (1982). Developing The Curriculum. Boston, Toronto : Little Brown and Company

Peraturan Presiden Republik Indonesia Nomor 87 tahun 2017

Rowse, A.L. (1963). The Use of History. London: Macmillan \& Co.

Setianto, Yudi. (2012). Dikotomi Bebas Nilai dan Nilai Pendidikan dalam Pembelajaran Sejarah. Jurnal Pendidikan dan Kebudayaan. Vol. 18, Nomor 4, Desember 2012.

Setianto, Yudi. (2018).Membangun Paradigma Baru Kurikulum Sejarah. Jurnal Karakter PPKn Dan IPS. Vol. 1, Nomor 1, Juli 2018.

Setiadi, Elly M., dkk. (2007). Ilmu Sosial dan Budaya Dasar. Cetakan ke-2. Jakarta: Kencana Prenada Media Group.

Soedjatmoko. (1990). Dimensi Manusia dalam Pembangunan. Jakarta: LP3ES

Sutopo,H.B. (2006). Metode Penelitian Kualitatif Dasar Teori dan Terapannya dalam Penelitian. Surakarta: Universitas Sebelas Maret

Tjandrasasmita, Uka. (1983). "Beberapa Saran untuk Penggarisan Pola Penulisan Biografi Pahlawan Nasional" dalam Pemikiran Biografi, Kepahlawanan dan Kesejarahan Suatu Kumpulan Prasaran Pada Berbagai Lokakarya Jilid I. Jakarta: Proyek Inventarisasi dan Dokumentasi Sejarah Nasional Direktorat Sejarah dan Nilai Tradisional

Widja, I Gde. (1989). Pengantar Ilmu Sejarah: Sejarah dalam Perspektif Pendidikan. Semarang: Satya Wacana. 